\title{
Ctenodrilus serratus (Schmidt), PRIMER REGISTRO PARA MEXICO DE LA FAMILIA CTENODRILIDAE (ANNELIDA: POLYCHAETA) CON CONSIDERACIONES BIOGEOGRAFICAS
}

\author{
por \\ Sergio Salazar Vallejo \\ Adriana Jorajuria \\ Lab. Ecología Bentónica y Contaminación \\ Depto. de Oceanología, C.I.C.E.S.E. \\ Ap. Postal 2732, Ensenada, B, C. \\ 22800 México \\ Octavio del Rincón \\ Lab. Acuicultura \\ Depto. de Oceanología, C.I.C.E.S.E. \\ Ap. Postal 2732, Ensenada, B. C. \\ 22800 México
}

\begin{abstract}
SALAZAR VALLEJO, S.I., O, del Rincón y A. Jorajuria, 1983. Ctenodrilus serratus (Schmidt), pimer registro para México de la familia Ctenodrilidae (Annelida: Polychaeta) con consideraciones biogengráficas. Ciencias Marinas, 9(2): 97-107.
\end{abstract}

\section{RESUMEN}

Ctenodrilus serratus se reporta por primera vez para México. Varios ejemplares fueron colectados en la fauna incrustante sobre balsas de ABS para cultivo de Crassostrea gigas, en Bahía San Quintín e Isla San Benito, Baja California, asociados con briozoos, otros poliquetos, crustáceos, tunicados, nemátodos y algas verdes (Ulva, sp.).

Se revisan las referencias sobre la biología de la especie y se enlistan los ambientes y las localidades donde se ha reportado. Este es el primer reporte de la especie en la biota incrustante.

C. serratus es una "especie" cosmopolita. Se discute su dispersión y su status específico.

\section{ABSTRACT}

Ctenodrilus serratus is reported for the first time for Mexico. Several specimens were collected on the fouling community on ABS floats used to culture Crassostrea gigas, in Bahia San Quintín and San Benito Island, Baja California. They were associated with bryozoans, other polychaetes, crustaceans, tunicates, nematodes and green algae (Ulva $\mathrm{sp}$.).

The references on the biology of this species are reviewed. The environments and localities where it has been reported are listed. This is the first record of the species in the fouling community.

C. serratus is a cosmopolitan "species". Its dispersion and specific status is discussed. 


\section{INTRODUCCION}

Ctenodrilus serratus (Schmidt) pertenece a la familia Ctenodrilidae Kennel, que junto con la familia Parergodrilidae Reisinger, constituyen el Orden Ctenodrilida (Fauchald, 1977).

$\mathrm{La}$ familia Ctenodrilidae incluye cuatro géneros y 13 especies (Salazar Vallejo y Del Rincón,, 1983), cuyos representantes residen en aguas someras, salvo una que es abisal (Hartman, 1965; Hartman, 1971, Hartman \& Fauchald, 1971).

C. serratus comprende individuos larviformes, de número reducido de segmentos. El prostomio, ventralmente ciliado, carece de apéndices; el peristomio es alargado y asetígero; la probóscide es del tipo muscular ventral. Los parapodios son birrámeos, pero los lóbulos parapodiales están reducidos. Las escasas setas presentan pocos dientes grandes. La dermis exhibe abundantes células glandulares o pigmentarias (Fauvel, 1927; Wilfert, 1973).

Esta especie ocurre en abundancia en acuarios o tanques de agua marina, lo que se debe a su rápida reproducción asexual (Hartman, 1944): el animal se fragmenta $y$ cada segmento o par de ellos, con excepción del acrón y pigidio, pueden regenerar un individuo entero (Dales, 1967; Gardiner, 1978).

Schroeder \& Hermans (1975) nominaron para $C$. serratus la reproducción asexual paratómica; es decir, aparecen individuos completos, reconocibles antes de la separación. El dorso de varios segmentos se modifica en zonas de separación sitas en medio del segmento, y se acompaña de la formación de un nuevo prostomio. Así, cada pieza incluye un septo y porciones de los segmentos adyacentes. El proceso no se restringe a segmentos somáticos sino que incluye al prostomio y al pigidio.

Tal proceso fue denominado ctenodrilización por Fauvel (1959) y considerado como el único tipo de reproducción del grupo. Más tarde se descubrió que ocasionalmente aparecen individuos sexuados y viví- paros. Esas formas sexuadas pueden ser hermafroditas protándricos o gonocóricos con dimorfismo sexual. Aunque se dice que la nutrición para el embrión procede de los vasos sanguíneos maternos (Barnes, 1977; Gardiner, 1978), Schroeder \& Hermans (1975, Tabla XI) lo dudan. Sin embargo, aparentemente la reproducción sexual en esta especie, no ha sido observada en el hemisferio occidental (MacGinitie \& MacGinitie, 1968).

La dieta de C. serratus parece ser variada. Wilfert (1973) afirmó que, en cultivo, C. serratus puede alimentarse de Dunaliella sp. (Chlorophyceae) y que en condiciones naturales, arrastran detritos con el labio inferior eversible obteniendo así diatomeas bénticas. Su amplia distribución puede observarse en la Tabla I.

Fauchald \& Jumars (1979) anotaron que una población en Isla de Santa Catalina, California, U.S.A., es comensal con erizos de mar, especialmente Centrostephanus coronatus y Strongylocentrotus franciscanus. Con cste último, se asocia también Flabelliderma commensalis, otro poliqueto (Fam. Flabelligeridae) y ambos vermes toman la coloración de erizo (Fauchald, 1977).

La fauna de anélidos poliquetos bentónicos de la Bahía de San Quintín está bicn conocida. Las contribuciones a este conocimiento se basan en un muestreo intensivo por Reish (1963) y en un muestreo extensivo por Calderón-Aguilcra (1982). Este último autor agregó cinco especies a la lista de especies locales.

En este trabajo extendemos el rango geográfico de $C$. serratus y caracterizamos su ccología mediante un análisis de la literatura.

\section{MATERIAL Y METODOS}

Los ejemplares, de dos a ocho setígeros, fueron colectados por $O$. del Rincón, en Bahía San Quintín (4 ejemplares, 1 jul. 1982) y en Isla San Benito (12 ejemplares, 15 oct. 1982), Baja California, como parte de las muestras de un estudio sobre bioincrustaciones en balsas de ABS para cultivo 
TABLA 1. Sitios donde se han colectado especímenes de $C$. serratus y referencias.

\begin{tabular}{|c|c|}
\hline Acuarios y Reservorios & $\begin{array}{l}\text { N. Carolina (Fransen, 1980), } \\
\text { Inglaterfa (Mar. Biol. Assoc., 1931), } \\
\text { Mediterráneo (Fauvel, 1927), } \\
\text { Japón (Sudzuki \& Sekiguchi, 1972), } \\
\text { California (Hartman, 1961, 1969; Blake, 1975). }\end{array}$ \\
\hline Litoral Rocoso & $\begin{array}{l}\text { Florida (Monro, 1933, Renaud, 1956), } \\
\text { Inglaterra (Mar, Biol. Assuc., 1931), } \\
\text { Francia (Fauvel, 1927), } \\
\text { Alemania (Hartmann-Schröder, 1971), } \\
\text { Yugoslavia (Wilfert, 1973), } \\
\text { British Columbia (Hobson \& Banse, 1981), } \\
\text { California (Rowe, 1980). }\end{array}$ \\
\hline Arrecifes Coralinos & Curazao (Augener, 1936). \\
\hline Sustratos Blandos & $\begin{array}{l}\text { Alemania (Hartmann-Schröder, 1971), } \\
\text { Angola (Hartmann-Schröder, 1974), } \\
\text { California (Hartman, 1944; MacGinitie \& MacGinitic, 1968; } \\
\quad \text { Reish \& Barnard, 1967), } \\
\text { I Galápagos (Westheide, 1981), } \\
\text { I Märshall (Reish, 1968). }\end{array}$ \\
\hline Simbiontes & $\begin{array}{l}\text { Centrostephanus coronatus, Flabelliderma commensalis } \\
\text { Strongylocentrotus franciscanus } \\
\text { California (Fauchald, 1977; Fauchald \& Jumars, 1979), } \\
\text { Dendropoma sp. (Vermetidae) } \\
\text { Golfo de Akkaba (Ben-Eliahu, 1976). }\end{array}$ \\
\hline Bioincrustaciones & $\begin{array}{l}\text { B. San Quintín e I. San Benito, B. C. México } \\
\text { (este reporte) }\end{array}$ \\
\hline
\end{tabular}

de Crassostrea gigas. El ABS es un polímero de uso común en tubería de desagües. Las balsas eran placas, de malla de $5 \mathrm{~cm}$ por $6 \mathrm{~cm}$, presentaban briozoos, otros poliquetos (Familia Nereidae y Syllidae), anfípodos, copépodos, tunicados, nemátodos, gastrópodos y algas verdes (Ulva sp.). Todos los especímenes están depositados en la colección de poliquetos del CICESE, clave de catálogo CTEN-1.

\section{RESULTADOS}

C. serratus (Schmidt) posee un cuerpo subcilíndrico contraído con 2 a 8 setígeros, afilándose hacia ambos extremos (Fig. 1a). El prostomio cónico y romo, está ciliado ventralmente; los órganos nucales son evidentes por estar más pigmentados. El peristomio es tan largo como el prostomio con una seta en algunos ejemplares. La probóscide es del tipo cojinete muscular ventral; tubo digestivo divisible claramente en esó-

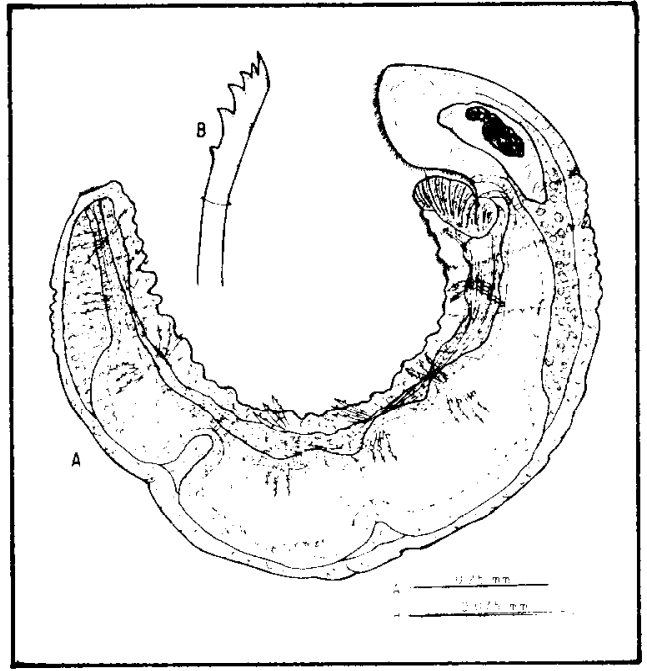

FIGUR A 1. Ctenodrilus serratus. A.- Vista lateral de un ejemplar completo, B.- Vista lateral de una seta anterior. 
fago, intestino anterior, intestino medio e intestino posterior. Los parapodios están reducidos; el primer setígero es unirrámeo, y los posteriores birrámeos, con 3-4 setas por haz; mayores en los segmentos anteriores. Las setas similares entre sí, con 5 dientes grandes, en ocasiones con un dentículo basal (Fig. 1b). La dermis es hialina, subhialina o con numerosas células pigmentarias, rojas o púrpuras, con partículas finas, extranas, adheridas a una matriz mucosa. Pigidio con ano término.dorsal; en algunos ejemplares, el ano está ciliado periféricamente.

\section{DISTRIBUCION}

C. serratus es una especie cosmopolita ya que se ha reportado de diversas latitudes (Tabla 1) en los tres grandes oceános (Müller, 1979; Pielou, 1979). La figura 2 muestra los sitios donde se ha reportado esta especie.

\section{DISCUSION}

Un complejo de eventos reproductivos similar al de $C$. serratus; es decir, reproducción asexual, formas hermafroditas pro- tándricas y formas gonocóricas, se han reportado en otros poliquetos (Género Ophryotrocha) de la familia Dorvilleidae (Akesson, 1975). Sin embargo, al estudiarlos en detalle, resultaron ser complejos de especies separables únicamente por su biología reproductiva (Akesson, 1978). Un estudio de este tipo para $C$. serratus no se ha intentado, a pesar de la relativa facilidad para mantenerlo en cautiverio (Wilfert, 1973).

C. serratus no se había reportado de Bahía San Quintín. Este es entonces el primer registro para la Bahía de San Quintín y para México.

C. serratus muestra una distribución tetiana (Fig. 2); es decir, se acerca a las áreas consideradas como pertenecientes a la cuenca del Tethys (Cf. Ekman, 1953, Fig. 23; Valentine, 1973 Fig. 9-2), o a derivados de esta misma cuenca (Pielou, 1979 Fig. 2-1). Aunque los términos cosmopolita y tetiana parecen contrarios, aclaramos que entendemos al primero en un sentido menos extenso que el término ubicuo, el cual según Müller (1979) se refiere a taxones eurioicos de distribución mundial, mientras que las especies

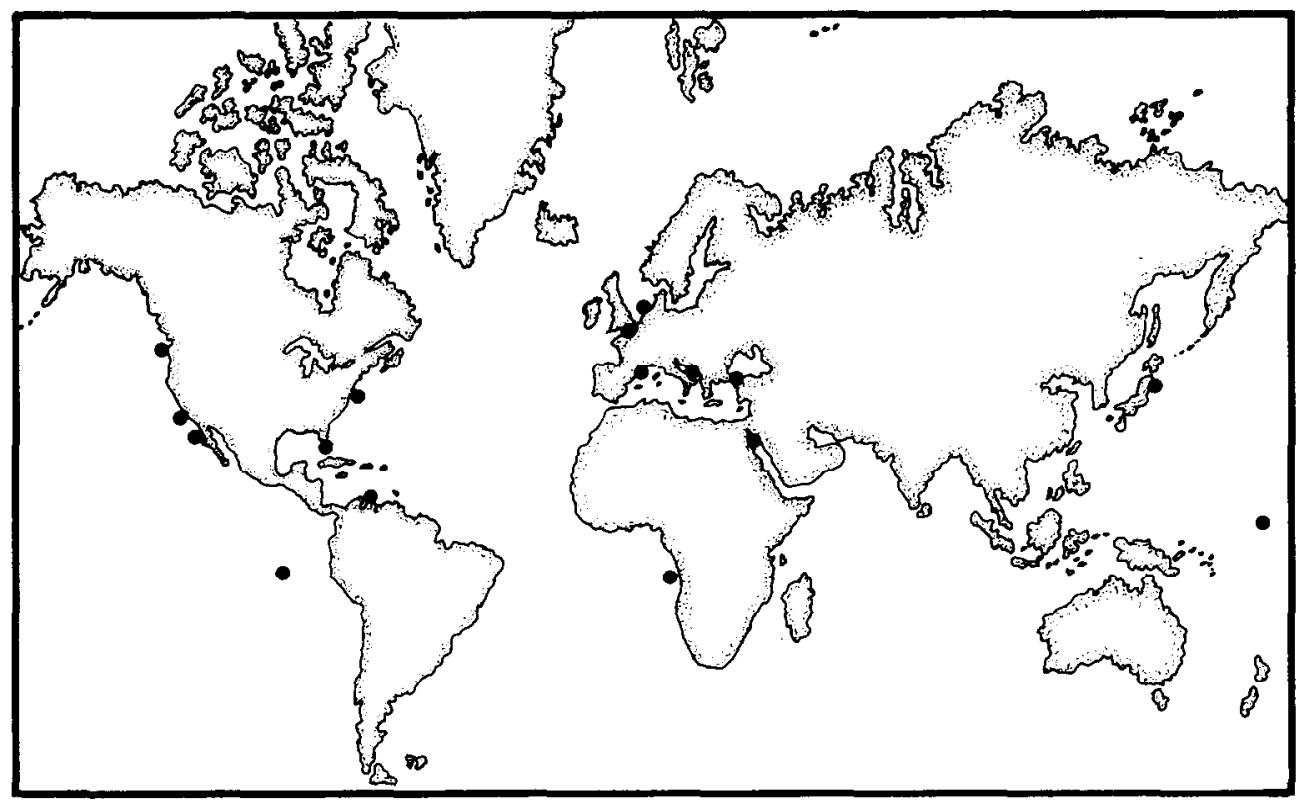

FIGURA 2. Distribución de Ctenodrilus serratus. Localidades reportadas: 
cosmopolitas se presentan en los tres grandes océanos, sin que necesariamente alcancen latitudes polares. Cuando esto ocurre, los términos cosmopolita y ubicuo son equivalentes. La presencia de una especie en los tres grandes océanos puede mostrar cierto patrón. En el caso de la distribución de $C$. serratus, su patrón distribucional es tetiano, pero por presentarse en los tres grandes océanos, es una especie cosmopolita. Podemos considerar que al carecer de estadios larvales, la especie haya sido transportada por algas bénticas, como lo hacen otras especies de poliquetos (Averincev, 1980) o utilizando algún otro método de dispersión pasiva por corrientes (Zinsmeister \& Emerson, 1979) para poder alcanzar este tipo de distribución. Sin embargo, por muy eficientes que estos medios fueran, resulta difícil concebir la existencia de flujo genético entre las distintas poblaciones de la especie. A partir de nuestro hallazgo, podemos considerar la posibilidad de que sean transportadas en las bioincrustaciones de los barcos; sin embargo, las diferencias ambientales son tan marcadas entre los sitios enlistados, que pensamos que C. serratus puede ser un complejo de especies cuyo ancestro común pudo sortear las distancias entre las diferentes poblaciones cuando existía un mar continuo (Tethys). La formación de barreras geográficas, ha permitido la diferenciación observada entre los residentes de distintas latitudes.

Además de la evidencia ecológica (Tabla 1), existen diferencias en las setas y en la pigmentación dérmica. Westheide (1981) comentó que las formas pacíficas y noratlánticas son ligeramente diferentes en estos caracteres. En adición, los dibujos de los ejemplares de Ben-Eliahu (1976) muestran una seta muy distinta a la de los nues tros, y los ejemplares provenientes del mismo sitio en las costas de Inglaterra, son ligeramente diferentes entre sí (Mar. Biol. Assoc., 1931).

En consecuencia, C. serratus podría considerarse como especie polimórfica o que constituye un complejo de especies. Estudios marísticos y/o de biología reproductiva arrojarán luz sobre este problema.

\section{AGRADECIMIENTOS}

La revisión de un escrito previo por A. Carvacho y L.F. Bückle resultó en notable mejoría. Dolores Peralta mecanografió el trabajo y Manuel Noriega hizo las ilustraciones. El primer autor es becario del CONACYT en CICESE. La fase final de este trabajo fue apoyada por CONACYT, proyecto PCCBCNA 020120.

\section{LITER ATURA CITADA}

AKESSON, B. 1975. Reproduction in the genus Ophryotrocha (Polychaeta, Dorvilleidae). Publ. Staz. Zool. Napoli, 39 (Suppl.): 377-398.

1978. A new Ophryotrocha species of the labronica group (Polychaeta, Dorvilleidae) revealed in crossbreeding experiments. In Marine Organisms: Genetics, Ecology and Evolution. Plenum Press, 573-590.

AUGENER, H. 1936. Polychaeten aus den marinen Salinen von Bonaire und Curacao. Zool. Jahrb. Abt. Syst. Oekol. Geogr. Tiere, 67:337-352.

AVERINCEV, V. G. 1980. The role of drifting islands of seaweeds in the distribution of bottom polychaetes. Mar Biol. (Vladivostok), 1:80-83.

BARNES, R.D. 1977. Zoología de los Invertebrados. 3a. Ed. Edit. Interam., xiv +826 pp.

BEN-ELIAHU, M.N. 1976. Poly chaete cryptofauna from rims of similar intertidal vermetid reefs on the Mcditerranean Coast of Israel and in the Gulf of Elat. Israel J. Zool., 25:121-155.

BLAKE, J.A. 1975. Phylum Annclida, class Polychaeta. In: Light's Manual, Intertidal Invertebrates of the Central California Coast. Univ. Calif. Press, 151-243. 
CALDERON-AGUILERA, L.E. 1982. Variaciones estacionales sobre algunas especies de poliquetos (Annelida: Polychaeta) de la Bahía de San Quintín Baja California, México. Tes. Prof., Fac. Cienc., UNAM 80 pp.

DALES, R.P. 1967. Annelids 2nd. Ed. Hutchinson Univ. Library, 200 pp.

EKMAN, S.1953. Zoogeography of the Sea. Sidgwick \& Jackson, xiv +417 pp.

FAUCHALD, K. 1977. The Polychaete worms, definitions and keys to the orders, families and genera. Nat. Hist. Mus. L.A. Cty., Sci. Ser., 28.1-90

FAUCHALD, K. AND P.A. Jumars. 1979. The diet of worms: A study of polychaete feeding guilds. Oceanogr. Mar. Biol. Ann. Rev., 17:193-284

FAUVEL, P. 1927. Polychetes sedentaires et addenda aux polychetes errantes. Faune de France, 16:1-494.

1959. Classe des annélids polychetes. Annelida, Polychaeta. (Grube 1851). In Traite de Zoologie, 5(1):12-196.

FRANSEN, M.E. 1980. Ultrastructure of coelomic organization in annelids, I. archiannelids and other small polychaetes. Zuomorphologie, 95(3): 235249.

GARDINER, M.S. 1978. Biología de los Invertebrados. Ed. Omega, viii +940 pp.

haRTMAN, O. 1944. Polychaetous Annelids, 6. Paranoidae, Magelonidae, Longosomidae, Ctenodrilidae and Sabellariidae. Allan Hancock Pac. Exped., 10(2-3):311-389.

1961. Polychaetous annelids from California. Ibid., 25:1-266.

1965. Deep-water Benthic Polychaetous Annelids of New England to Bermuda and Other North Atlantic Areas. Allan Hancock Found, Publ. Occ. Pap., 28:1-378.

1967. Phylum Annelida, class Polychaeta. In: Intertidal Invertebrates of the Central California Coast. Univ. Calif. Press, 63-107.
1969. Atlas of the Sedentariat Polychaetous Annelids from California. Hancock Found., Univ. So. Calif., 812 pp.

1971. Abyssal polychaetous annelids from the Mozambique Basin of Southeast Africa, with a compendium of abyssal polychaetous annelids from world-wide areas. J. Fish. Res. Bd. Canada, 28(10): 1407-1428.

HARTMAN, O. and K. Fauchald. 1971. Deepwater benthic poly chaetous annelids of New England to Bermuda and other North Atlantic areas, 2. Allan Hancock Monogr. Mar. Biol., 6:1-327.

HARTMANN-SCHRÖDER, G. 1971. Annelida, Borstenwürmer, Polychaeta. Tierwelt Deutschlands, 58:1-594.

1974. Zur Kenntnis des Eulitorals der Afrikanischen Westküste Swischen Angola und Kap der Guten Hoffnung und der Afrikanischen Ostküste von Sudafrika und Mocambique unter besonderer Berücksichtigung der Polychaeten und Ostracoden Teil II. Die Polychaeten des Unterschungsbetietes. Mitt. Hamb. Zool. Mus. Inst., Ergbd., 69:95-228.

HOBSON, K. D. and K. BANSE. 1981. Sedentariate and archiannelid polychaetes of British Columbia and Washington. Can. Bull. Fish. Aquat. Sci., 209: viii + 144 .

MacGINITIE, G. E. and N. MacGinitie. 1968. Natural History of Marine Animals. 2nd. Ed. MoGraw-Hill $423 \mathrm{pp}$.

MARINE BIOLOGICAL ASSOCIATION 1931. Plymouth Marine Fauna. 2nd. Ed. Mar. Biol. Assoc. U.K., 371 pp.

MONRO, C. C. A. 1933. On a collection of Polychaeta from Dry Tortugas, Florida. Ann. Mag. Nat. Hist. London Ser. 10, 12:244. 269.

MÚLLER, P. 1979. Zoogeografía. Blume, 232 pp.

PIELOU, E. C. 1979. Biogeography. John Wiley \& Sons, $x i i+351 \mathrm{pp}$. 
REISH, D. J. 1963. A quantitative study of the benthic polychaetous annelids of Bahía de San Quintín, Baja California. Pac. Nat., 3(14):401-436.

1968. The polychaetous annelids of the Marshall Islands. Pac. Sci., 22(2):208-231

REISH, D.J. and J. L. Barnard. 1967 The benthic Polychaeta and Amphipoda of Morro Bay, California. Proc. U.S. Natl. Mus., 120(3565):1-26.

RENAUD, J.C. 1956. A report on some polychaetous annelids fron the Miami-Bimini area. Amer. Mus. Novit., 1812:1-39.

ROWE, R. 1980. Polychaeta. In: A Taxonomical Listing of Common Marine Invertebrates Species fron Southern California. Allan Hancock Tech. Rep., 3:78-129.

SALAZAR-VALLEJo, S. 1. y O. Del Rincón. 1983. Revisión parcial de la Familia Ctenodrilidae Kennel 1882. (Annelida: Polychaeta: Ctenodrilida). Mem. 6o. Congr. Nac. Zool., (en Prensa).
SCHROEDER, P. C. and C. O. Hermans. 1975. Annelida: Polychacta. In: Reproduction of Marine Invertebrates. Academic Press, 3:1-213.

SUDZUKI, M. and K. Sekiguchi. 1972. Some remarks on five aberrant annelids fron the culture water of Japanese Horse-Shoe Crabs. Scient. Rep. Tok yo K yoiki Daigaku (B), 15(223): 39-59

VALENTINE, J. W. 1973. Evolutionary Paleoecology of the Marine Biosphere. PrenticeHall, $x v+511 \mathrm{pp}$.

WESTHEIDE, W. 1981. Interstitielle Fauna con Galapagos. XXVI. Questidae, Cirratulidae, Acrocirridae, Ctenodrilidae (Polychacta). Mikrofauna Meeres., 82:58-79.

WILFERT, M. 1973. Ein Beitrag Zur Morphologie, Biologie und Systematischen Stellung des Polychaeten Ctenodrilus serratus. Helgolander Wiss. Meeresunters., 25:332-346.

ZINSMEISTER, W. J. and W. K. Emerson. 1979. The role of passive dispersal in the distribution of hemipelagic invertebrates, with examples fron Tropical Pacific Ocean. Veliger, 22(1):32-40. 


\title{
Ctenodrilus serratus (Schmidt), FIRST RECORD FOR MEXICO OF THE FAMILY CTENODRILIDAE (ANNELIDA: POLYCHAETA) WITH BIOGEOGRAPHIC CONSIDERATIONS.
}

\author{
by \\ Sergio Salazar Vallejo \\ Adriana Jorajuria \\ Lab. Ecología Bentónica y Contaminación \\ Depto. de Oceanología, C.I.C.E.S.E. \\ Apdo. Postal 2732, Ensenada, B. C. \\ 22800 Mexico \\ and \\ Octavio del Rincón \\ Lab. Acuicultura \\ Depto. de Oceanología, C.I.C.E.S.E. \\ Apdo. Postal 2732, Ensenada, B. C. \\ 22800 México
}

SALAZAR-VALLEJO, S.I., O. del Rincón and A. Jorajuria, 1983. Ctenodrilus serratus (Schmidt), first record for Mexico of the family Ctenodrilidae (Annelida: Polychaeta) with biogeographic considerations. Cienciás Marinas, $9(2): 97-107$.

\section{INTRODUCTION.}

Ctenodrilus serratus (Schmidt) belongs to the family Ctenodrilidae Kennel, which together with the family Parergodrilidae Reisinger, make up the order Ctenodrilida (Fauchald, 1977).

The family Ctenodrilidae includes four genera and 13 species (Salazar-Vallejo y Del Rincón, 1983), whose members reside in shallow water, excepto one species which is abyssal (Hartman, 1965; Hartman, 1971; Hartman \& Fauchald, 1971).

C. serratus is a maggot-shaped polychaete, with a reduced number of segments. The prostomium, ventrally ciliated, lacks apendices; the peristomium is elongated and asetigerous; the proboscis is of the ventral muscular pad type. The parapodia are biramous, but the parapodial lobes are reduced. The scarce setae have few coarse teeth. The body wall has many pigment or gland cells (Fauvel, 1927; Wilfert, 1973).

This species occurs abundantly in marine tanks or aquaria, because it has a very rapid asexual reproduction (Hartman, 1944); the animal breaks off' and each seg- ment or pair of them, except for the acron or the pygidium, regenerate an entire organism (Dales, 1967; Gardiner, 1978).

Schroeder \& Hermans (1975) noted the paratomic asexual reproduction; they seem to be distinct organisms before the separation. The dorsum of several segments modifies in abscision zones in the middle of the segment, and is accompanied by the formation of a new prostomium. Thus, each piece includes a septum and portions from adjacent segments. This process is not restricted to somatic segments but includes the prostomium and the pygidium as well.

Such a process was denominated ctenodrilization by Fauvel (1959) and regarded as the only type of reproduction among the group. Later, it was discovered that eventually appear sexual and viviparous individualls. These sexual forms are protandric or gonochoric with sexual dimorphism. Although it is supposed that the nutrition for the embryo comes from the maternal blood vessels (Barmes, 1977; Gardiner, 1978) Schroeder \& Hermans (1975, Table XI) doubt it. However, it seems that sexual reproduction in this species has not been observed in the Western Hemisphere (McGinitie, \& McGinitie, 1968). 


\section{SERRATUS FIRST RECORD}

The diet of $C$. serratus seems to be varied. Wilfert (1973) reported that in culture, $C$. serratus my be fed on Dunaliella sp. (Chlorophyceae) and that in natural conditions, they pull detritus with the eversible lower lip, thusly obtaining benthic diatoms. Their distribution seems to be in agreement with their diet (Table I).

Fauchald \& Jumars (1979) reported that a population in Santa Catalina Island, California, U.S.A., is commensal with sea urchins especiallyCentrostephanus coronatus and Strongylocentrotus franciscanus. With the latter, another polychaete is associated, Flabelliderma commensalis (Fam. Flabelligeridae); both worms take the sea urchin coloration (Fauchald, 1977).

The polychaete fauna from San Quintın Bay is rather well know. The main contributions to this knowledge are based on an intensive sampling by Reish (1963) and on an extensive sampling by Calderón-Aguilera (1982). The latter added five species to the local species list.

In this paper we extend the geographic range of $C$. serratus and characterize their ecology through a bibliographic analysis.

\section{MATERIAL AND METHODS.}

The specimens with two to eigth setigers were collected by $O$. del Rincón in San Quintin Bay (4 specimens, 1 Jul. 1982) and in San Benito Island (12 specimens, 15 Oct. 1982), Baja California, as part of the samples from a study on the fouling community on ABS floats to culture Crassostrea gigas. The ABS plastic is a commonly used polymer in sewage canery. The floats were plates measuring $5 \mathrm{~cm}$ by $6 \mathrm{~cm}$, and had bryozoans, other polychaetes (Families $\mathrm{Ne}$ reidae and Syllidae), amphipods, copepods,

TABLE I. Countries where Ctenodrihs serratus has been collected and references.

\begin{tabular}{|c|c|}
\hline Acuarios y Reservorios & $\begin{array}{l}\text { N. Carolina (Fransen, 1980), } \\
\text { Inglaterra (Mar. Biol. Assoc., 1931), } \\
\text { Mediterráneo (Fauvel, 1927), } \\
\text { Japón (Sudzuki \& Sekiguchi, 1972), } \\
\text { California (Hartman, 1961, 1969; Blake, 1975). }\end{array}$ \\
\hline Litoral Rocoso & $\begin{array}{l}\text { Florida (Monro, 1933, Renaud, 1956), } \\
\text { Inglaterra (Mar, Biol. Assoc., 1931), } \\
\text { Francia (Fauvel, 1927), } \\
\text { Alemania (Hartmann-Schröder, 1971), } \\
\text { Yugoslavia (Wilfert, 1973), } \\
\text { British Columbia (Hobson \& Banse, 1981), } \\
\text { California (Rowe, 1980). }\end{array}$ \\
\hline Arrecifes Coralinos & Curazao (Augener, 1936). \\
\hline Sustratos Blandos & $\begin{array}{l}\text { Alemania (Hartmann-Schröder, 1971), } \\
\text { Angola (Hartmann-Schröder, 1974), } \\
\text { California (Hartman, 1944; MacGinitie \& MacGinitic, 1968; } \\
\quad \text { Reish \& Barnard, 1967), } \\
\text { I Galápagos (Westheide, 1981), } \\
\text { I Marshall (Reish, 1968). }\end{array}$ \\
\hline Simbiontes & $\begin{array}{l}\text { Centrostephanus coronatus, Flabelliderma commensalis } \\
\text { Strongylocentrotus franciscanus } \\
\text { California (Fauchald, 1977; Fauchald \& Jumars, 1979), } \\
\text { Dendropoma sp. (Vermetidac) } \\
\text { Golfo de Akkaba (Ben-Eliahu, 1976). }\end{array}$ \\
\hline Bioincrustaciones & $\begin{array}{l}\text { B. San Quintín e I. San Benito, B. C. México } \\
\text { (este reporte) }\end{array}$ \\
\hline
\end{tabular}


tunicates, nematodes, gastropods and green algae (Ulva, sp.) attached to them. All the specimens are deposited in the polychaetes collection of CICESE, number CTEN-1.

\section{RESULTS}

C. serratus (Schmidt) has a subcylindrical contracted body with two to eight setigers, tapering to both ends (Fig. 1a). The conical prostomium is ventrally ciliated; the nuchal organs are evident as darker structures. The peristomium is as long as the prostomium with a setae in several specimens. The proboscis is of the ventral muscular pad. The digestive tube is clearly separated in esophagus, anterior, median, and posterior intestine. The parapodia are reduced; the first setiger is uniramous, and the posterior ones are biramous, with 3 to 4 setae per bundle; larger in the anterior segments. The setae are alike, with 5 coarse teeth, sometimes with a basal denticle (Fig. 1b), The body wall is hyaline, subhyaline or with many pigment cells, red or purple, with fine particles embedded in a mucous matrix. The pygidium bears a terminodorsal anus, in some specimens, there is a circle of cilia around the anus.

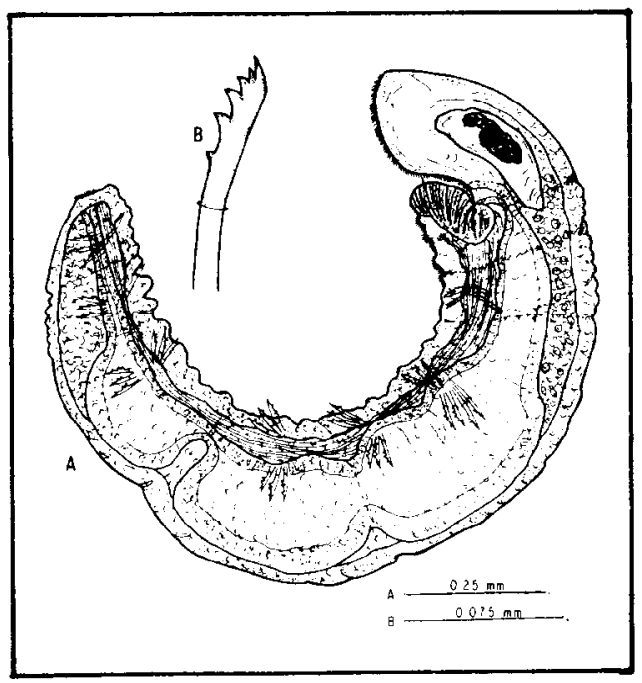

FIGURE 1. Ctenodrilus serratus. A.- Lateral view of a specimen. B.- Lateral view of an anterior setae.

\section{DISTRIBUTION}

C. serratus is a cosmopolitan species because it has been reported from various latitudes (Table 1) in the three main oceans (Muller, 1979; Pielow, 1979). The figure 2 shows the sites where this species has been reported.

\section{DISCUSSION}

A complex reproductive cycle, similar to the one of $C$. serratus; i. e., asexual reproduction, hermaphroditic protandric and gongochoric forms, has been reported in other polyhcaetes (Genus Ophryotrocha) of the family Dorvilleidae (Akesson, 1975). However, when those events were studied in detail, it resulted in a species complex to be separated only on the basis of their reproductive biology (Akesson, 1978). An analysis of this sort for $C$. serratus has not been attempted, even though they are relatively easy to be kept in captivity (Wilfert, 1973).

C. serratus has not been reported from San Quintín Bay. This is the first record for San Quintín Bay and for Mexico.

C. serratus shows a tethyan distribution (Fig. 2); i. e., it is close to the areas regarded as part of the Tethys basin ( $C f$. Ekman., 1953 Fig. 23; Valentine, 1973 Fig. 9-2), or to derivates of this basin (Pielou, 1979 Fig. 2-1). Although the terms cosmopolitan and tethyan seems contrary, we understand the first in a less extense sense than the term ubiquous, which according to Müller (1979) refers to eurioical taxa of worldwide distribution, while the cosmopolitan species are present in the three major oceans, not necessarily being present in polar latitudes. When this happens, the terms cosmopolitan and ubiquous become equivalent. The presence of a species in the three oceans may show a certain pattern. In the case of C. serratus distribution, the pattern is tethyan, but because it is present in the three major oceans it is a cosmopolitan species. This species disperses by means of drifting benthic algae, as do other polychaete specics (Averincev, 1980), or by employing passive dispersal by currents (Zinsmeister \& Emerson, 1979). However, even though 


\section{SERRATUS FIRST RECORD}

these dispersal means might be important, it is hard to believe that there is a genetic interchange among the different populations of this species.

From our findings it seems that they are dispersed in the fouling on the ships; however, the environmental differences are so markedly distinct among the listed sites, that we think that $C$. serratus mighth be a species complex whose ancestors could disperse through the continous Tethys Sea. The make up of geographic barriers has favored the observed differentiation among the residents of diferent places.

Apart of the ecological evidence (Table 1), there are differences in the setae and body wall pigmentation. Westheide (1981) noted that Pacific North Atlantic forms were different on these characters. In addition, the specimens drawed by BenEliahu (1976) had a very different setae than ours, and the specimens collected in the same site in England coasts, are sligthly different among themselves (Mar. Biol. Assoc., 1931).

As a consequence, $C$. serratus could be regarded as a polymorphic species or that it is a species complex. Further meristic and/ or reproductive biology studies will throw light on this problem.

\section{ACKNOWLEDGEMENTS.}

The review of a previous draft by $\mathrm{A}$. Carvacho and L.F. Bückle resulted in great improvement. Dolores Peralta typewrited the paper and Manuel Noriega made the illustrations. The first author is a research assistant of CONACYT, project PCCBCNA 020120.

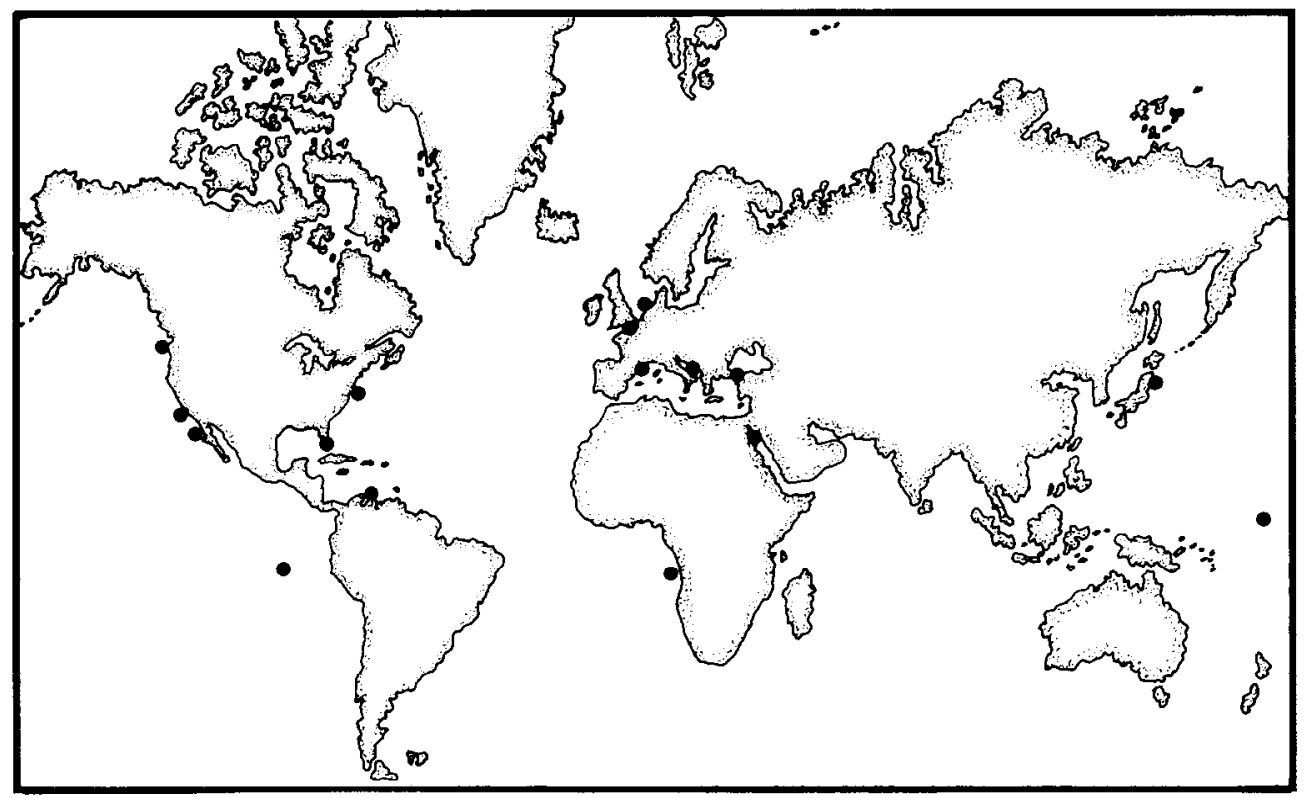

FIGURE 2. Distribution of Ctenodrilus serratus. Reported localities. 